Chirurgia (2021) 116: 135-142

No. 2, March - April

Copyright@ Celsius

http://dx.doi.org/10.21614/chirurgia.116.2.135

\title{
Robotic Prophylactic Nipple-Sparing Mastectomy with Immediate Prosthetic Breast Reconstruction: A prospective Study of 138 Procedures
}

\author{
Claire Sanson*, Aurélie Roulot, Jean-François Honart, Françoise Rimareix, Nicolas Leymarie, Benjamin Sarfati \\ Department of Plastic and Reconstructive Surgery, Gustave Roussy, Villejuif, France
}

\author{
${ }^{*}$ Corresponding author: \\ Claire Sanson, MD \\ Department of Plastic and \\ Reconstructive Surgery \\ Gustave Roussy, Villejuif, France \\ E-mail: claire.sanson@gustaveroussy.fr \\ Abbreviations: \\ NSM: nipple sparing mastectomy; \\ $\mathrm{BC}$ : breast cancer; \\ RNSM: robotic nipple-sparing \\ mastectomies; \\ IBR: $\quad$ immediate breast reconstruction;
}

\section{Rezumat \\ Mastectomia profilactică robotică cu prezervarea mamelonului cu reconstrucție mamară protetică imediată: un studiu prospectiv de 138 de proceduri}

Context: Chirurgia robotică a sânului este o procedură emergentă cu rezultate preliminare încurajatoare. Scopul acestui studiu este de a evalua fezabilitatea şi siguranța mastectomiei robotice cu prezervarea mamelonului (MRPM) cu reconstrucție mamară protetică imediată (RMPI).

Metode: Acesta este un studiu prospectiv care include din decembrie 2015 până în ianuarie 2020 toate operațiile MRPM cu RMPI, la pacientele cu ptoză moderată şi cupa A, B sau C. Criteriul principal de evaluare a fost rata de necroză majoră. Punctele finale secundare au fost rata de conversie, complicatiiile postoperatorii (infecții, hematom, expunerea implantului), rezultatele estetice şi calitatea vieții.

Rezultate: Studiul include un număr de 79 paciente la care s-a practicat 138 mastectomii robotice cu prezervarea mamelonului cu reconstrucție mamară protetică imediată. Pacientele au fost urmărite pe o perioadă medie de 28 de luni. 2 proceduri au necesitat conversie. S-au înregistrat două cazuri de necroză majoră $(1,4 \%)$. Au fost observate 9 infectiii de plagă chirurgicală $(6,5 \%)$, dintre care 4 au fost tratate prin înlocuirea implantului iar 5 au dus la pierderea implantului. Pierderea implantului a fost înregistrată în alte 4 cazuri: 2 din cauza necrozei majore şi 2 din cauza capsulei periprotetice. In total, s-au pierdut un număr de 9 implanturi $(6,5 \%)$. Rezultatele estetice au fost în mare parte foarte satisfăcătoare, iar calitatea vieții nu a fost afectată de mastectomie. 
Concluzii: Mastectomie robotică cu prezervarea mamelonului cu reconstrucție mamară protetică imediată a fost asociată cu rate scăzute de necroză majoră. Aceasta este o procedură sigură şi reproductibilă care permite reconstrucția sânului fără cicatrici vizibile.

Cuvinte cheie: mastectomie robotică, reconstrucție mamară, chirurgie minim invazivă, mastectomie cu prezervarea complexului areolo-mamelonar, chirurgie profilactică

\begin{abstract}
Background: Robotic breast surgery is an emergent procedure with encouraging preliminary results. The aim of this study is to assess the feasibility and the safety of robotic nipple sparing mastectomy (RNSM) with immediate prosthetic breast reconstruction (IPBR).

Methods: This is a prospective study including from December 2015 to January 2020 all RNSM surgeries with IPBR, in patients with moderate ptosis and A B or C cup. The primary endpoint was the rate of major necrosis. Secondary endpoints were conversion rate, postoperative complications (infections, hematoma, implant exposure), aesthetic results and quality of life.

Results: 79 patients underwent 138 RNSM with IPBR. The average follow-up was 28 months. 2 procedures required conversion. Two cases of major necrosis occurred (1.4\%). 9 surgical site infections were observed (6.5\%), 4 infections could be treated with implant replacement. Unfortunately, 5 others resulted in implant loss. 4 other implant losses occurred: 2 due to major necrosis, and 2 due to periprosthetic capsula. In total, 9 implants were lost (6.5\%). Esthetical results were mostly very satisfying and quality of life was not affected by the mastectomy.

Conclusions: RSNM with IPBR was associated with low rates of major necrosis. It is a safe and reproducible procedure that allows breast reconstruction without visible scar.
\end{abstract}

Key words: robotic mastectomy, breast reconstruction, minimal invasive surgery, nipple-sparing mastectomy, prophylactic surgery

\section{Introduction}

Nipple sparing mastectomy (NSM) is today considered as a valid procedure for prophylactic mastectomy and an acceptable option for breast cancer (BC) therapeutic mastectomy $(1,2)$. An increasing number of women are choosing mastectomy for risk reduction. Consequently, the demand to improve cosmetic results in breast reconstruction is rising steadily.

However, NSM is technically challenging because of exposure difficulties. Surgical approach is therefore crucial since oncologic safety and reconstruction success depend on it. Indeed, exposure problems could lead to incomplete resection or surgical complications such as cutaneous necrosis (3). Moreover, peri- areolar or radial incisions are associated with nipple-areola complex deformation or malposition $(4,5)$.

Endoscopic nipple-sparing mastectomy procedure has been developed to overcome these complications (6-8). However, using rigid endoscopic instruments with a twodimensional endoscopic camera is highly technically challenging and has thus not led to the popularity of this technique (9). Using robotic surgery in nipple-sparing mastectomies can enable enhanced exposure which allows for improved preservation of the vasculature to the mastectomy flap. The insufflation provided by robotic surgery replaces the need for retraction which decreases the subsequent damage caused by aggressive retraction on the mastectomy flap. 
Robotic surgery has been largely developed in oncologic surgery, with satisfactory outcomes. These experiences lead us to start breast robotic surgery development (10-13).

Very few studies of robotic mastectomy were reported (14-17), with encouraging preliminary results.

The aim of this study was to report feasibility of robotic NSM with a large series of 138 procedures.

\section{Patients and Methods}

This is a prospective descriptive monocentric study. Robotic nipple-sparing mastectomies (RNSM) and immediate breast reconstruction (IBR) were performed by one surgeon during 4 years (from December 2015 to January 2020).

\section{Patient Selection}

Patients had to meet the following criteria: breast cup size A, B or C (based on bra size) and ptosis grade $\leq 2$ (Regnault ptosis scale) (otherwise a skin-reducing nipple-sparing mastectomy was indicated). Patients with high risk of cutaneous necrosis were excluded: strong tobacco intoxication ( $>1$ pack per day), uncontrolled diabetes mellitus, history of breast surgery or breast radiation. A breast imaging (ultrasound, mammography, or MRI scan) was done during the preceding 6 months. All indications were validated in multidisciplinary meetings. Before the procedure, every patient provided signed informed consent for RNSM with IPBR according to the established regulations.

\section{Design}

The study was performed in accordance with the Good Clinical Practice guidelines and the Declaration of Helsinki. The institutional review board at Gustave Roussy, an ethics committee, and health authorities approved the study protocol.

The primary study endpoint was the rate of major necrosis (mastectomy skin flap or NAC necrosis that requires surgery). Secondary endpoints included the conversion rate to open technique, post-operative complication rate (hematoma, infection, implant exposure), esthetical results and quality of life.

Esthetical results were evaluated by the patient herself and by the surgeon at 6 and 12 months after surgery, and also by four independent plastic surgeons, from pictures taken 6 months after surgery (frontal, profile, and three quarter). Quality of life was studied comparing pre-operative and 12 -months postoperative BREAST-Q results.

\section{Surgical Procedures}

All procedures were performed with the da Vinci $^{\circledR}$ XITM (Intuitive Surgical ${ }^{\circledR}$, Sunnyvale, CA). A lateral-thoracic approach is associated with a high vertical scar of $3-5 \mathrm{~cm}$, located within the footprint of the bra, with a subcentimeter vertical scar, located $8-9 \mathrm{~cm}$ below the previous incision. These incisions are located 6-7 cm behind the lateral-mammary fold.

Patients' installation was dorsal decubitus, with arm overhead (90 degrees abduction and internal rotation, elbow at 90 degrees). Infiltration with a saline solution containing $1 \mathrm{mg} / \mathrm{mL}$ of adrenaline was used to reduce bleeding and to facilitate subcutaneous dissection of the gland. Subcutaneous dissection was then performed as far as possible with scissors. Before inserting ports, we ensured that dissection was confluent between the two incisions to allow insertion of the instruments under endoscopic vision. The upper incision was closed, and three 8-mm diameters ports were inserted and fixed with stitches to the skin incision. Robot docking was guided by the target sign, which had to be aligned with both the skin incision and the nipple. Carbon dioxide insufflation $(8 \mathrm{mmHg}, 10 \mathrm{~L} / \mathrm{min}$ ) created an adequate working space for the robot. The $30^{\circ}$ camera (Intuitive Surgical ${ }^{\mathbb{}}$, Denzlingen, Germany) was introduced first in the middle port to allow non-traumatic insertion of the monopolar-curved scissors and the bipolar grasping forceps (Intuitive Surgical ${ }^{\mathbb{Q}}$, Sunnyvale, CA). Subcutaneous dissection of the gland was completed in a lateral to medial direction, up to the limits of the gland. Then, 
the gland was separated from the pectoralis major muscle in a lateral to medial direction. The robot was undocked and the ports were removed. The gland was then extracted, oriented, and sent for pathological examination. A drain was placed through the inferior infracentimetric scar. The anatomical implant was inserted in a prepectoral position. Finally, the implant pocket was closed laterally to avoid any secondary malposition of the prosthesis (Fig. 1).

\section{Statistics}

Categorical variables are summarized in frequency tables, with the counts and percentages of patients in each category. For continuous variables, summary statistics include number of patients, mean and range (Excel). For the comparison of means, we used a Student test.

\section{Results}

\section{Patients}

From December 2015 to January 2020, a total of 79 women underwent 138 RNSM with IPBR (Table 1). For $75 \%$ of patients, it was a bilateral prophylactic mastectomy. The weight of resected tissue ranged between 87 and 590 g. Mean follow-up was 28 months.

\section{Operating Time}

Operating time decreased considerably overtime: from 214 to 85 minutes per breast. Docking time has been reduced from 47 to 5 minutes. Mastectomy length could vary from 20 to 83 minutes, depending on breast volume and surgeon's experience).

\section{Conversions}

Two procedures $(1.4 \%)$ were converted to an open technique: the first one because of a bleeding from an internal mammary perforator that could not be controlled endoscopically. The second conversion was due to exposure difficulties with a large fatty breast. Post-oper ative complications (Table 2).

We noted 2 cases of major skin flap or NAC
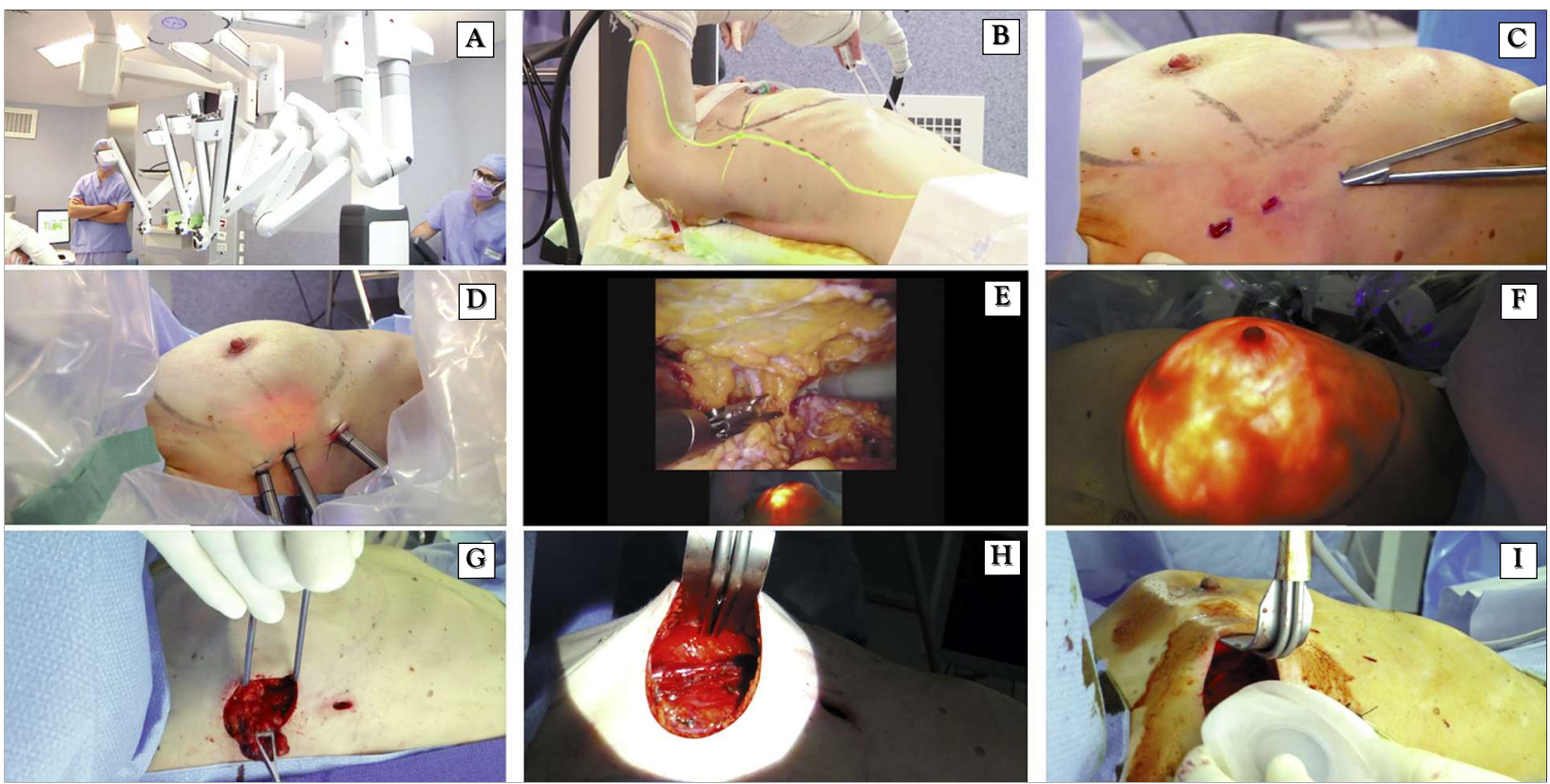

Figure 1. Surgical procedure: Presentation of the robot Da Vinci $X i^{\circledR}(\mathbf{A})$ - Position of the patient (B) - After infiltration and realization of three $8 \mathrm{~mm}$ incisions, dissection subcutaneous as far as possible with scissors (C) - Placement of the 3 ports and insufflation (D) - Continuation of the dissection with robotic instruments (E, F) - Extraction of the gland through an incision $(<5 \mathrm{~cm})$ joining the 3 ports incisions $(\mathbf{G})$ - Placement of the prosthesis $(\mathbf{H}, \mathbf{I})$ 
Table 1. Patient characteristics $(\mathrm{N}=79)$ and mastectomy characteristics $(\mathrm{N}=138)$

\begin{tabular}{lc}
\hline Age, years, median (range) & $37.4(23-56)$ \\
\hline BMl, kg/m², median (range) & $21.16(17-34)$ \\
\hline Chest size, number of patients (\%) & $2(2.5)$ \\
$75 \mathrm{~cm}$ & $3(3.8)$ \\
$80 \mathrm{~cm}$ & $19(24.1)$ \\
$85 \mathrm{~cm}$ & $41(51.9)$ \\
$90 \mathrm{~cm}$ & $9(11.4)$ \\
$95 \mathrm{~cm}$ & $2(2.5)$ \\
$100 \mathrm{~cm}$ & $3(3.9)$ \\
NA & \\
Cup size, number of patients (\%) & $11(13.9)$ \\
A & $47(59.5)$ \\
B & $21(26.6)$ \\
C & \\
\hline Regnault ptosis scale, number of patients (\%) & $46(58.2)$ \\
0 & $23(29.1)$ \\
1 & $5(6.3)$ \\
2 & $3(3.8)$ \\
pseudoptosis & $2(2.5)$ \\
Missing & \\
\hline Pinch test, number of patients (\%) & $22(27.8)$ \\
$<1 \mathrm{~cm}$ & $37(46.8)$ \\
{$[1 ; 2 \mathrm{~cm}]$} & $4(5.1)$ \\
$>$ N 2 cm & $16(20.3)$ \\
NA & $2(2.5)$ \\
Smoking history & $6(7.6)$ \\
Current & $59(74.7)$ \\
Past & \\
Bilateral surgery (\%) & \\
\hline
\end{tabular}

necrosis, leading to a rate of $1.4 \%(2 / 138)$ (Table 2). Nine surgical site infections occurred (6.5\%). Four infections were successfully managed with revision surgery to wash the implant pocket and to replace the implant.
Table 2. Operating data and post-operative follow-up

\begin{tabular}{lc}
\hline Number of patients & 79 \\
\hline Number of mastectomies & 138 \\
\hline Gland weight (g) & $206(87-590)$ \\
\hline Drain removal (day) & $6.6(3-12)$ \\
\hline Conversion & $3(2.2)$ \\
\hline Complications: & $22(15.9)$ \\
Necrosis & $2(1.5)$ \\
Hematoma requiring reoperation & $4(2.9)$ \\
Infection & $9(6.5)$ \\
\hline Implant loss: & $9(6.5)$ \\
- Infection: & $5(3.6)$ \\
- Necrosis: & $2(1.5)$ \\
- Periprosthetic capsula: & $2(1.5)$ \\
\hline Seroma & $7(5.1)$ \\
\hline Operating time (h) & $4.4(2.57-7.18)$ \\
\hline Follow-up (months) & $28.2(3-52)$ \\
\hline
\end{tabular}

Unfortunately, five infections led to implant loss.

We reported 4 other implant losses: 2 following skin flap or NAC necrosis, and 2 due to severe periprosthetic capsula.

Finally, a total of nine implants were lost in our 138-patients cohort, corresponding to a rate of $6.5 \%$.

\section{Esthetical Results and Quality of Life}

The 12-month follow-up was available in 47 of 79 patients. Analysis of esthetical results by both surgeon and patient was consistent: satisfying or very satisfying for the vast majority (Table 3), (Fig. 2).

Figure 2. Preoperative (A) and postoperative (B) photos at one year after surgery

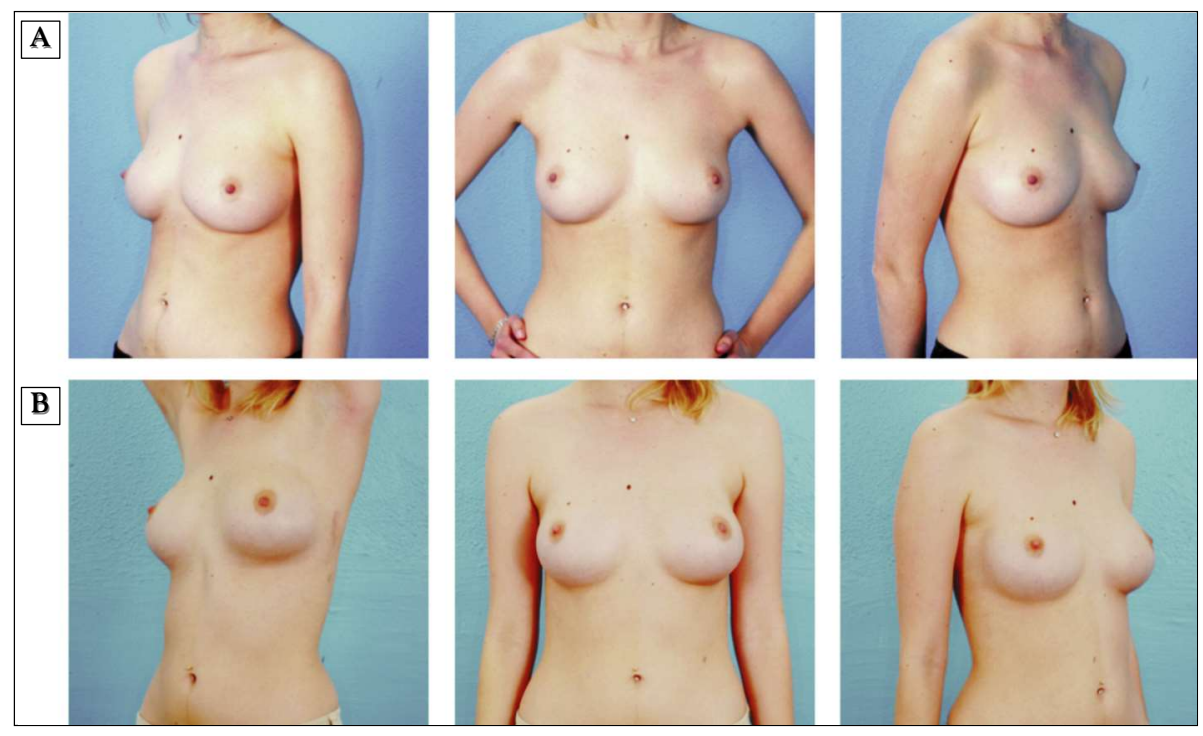


Table 3. Esthetical results evaluated by the patient herself and by the surgeon at 6 and 12 months after surgery: A very satisfying; $B$ satisfying; $C$ mixed result; $D$ unsatisfactory

\begin{tabular}{lcc}
\hline & Patient & Surgeon \\
\hline Breast volume & & \\
A & 25 & 31 \\
B & 21 & 8 \\
C & 1 & 1 \\
D & 0 & 0 \\
Missing & 0 & 7 \\
\hline Breast shape & & \\
A & 17 & 22 \\
B & 28 & 13 \\
C & 2 & 4 \\
D & 0 & 1 \\
Missing & 0 & 7 \\
\hline Breast position & & \\
A & 26 & 22 \\
B & 18 & 14 \\
C & 2 & 4 \\
D & 1 & 0 \\
Missing & 0 & 7 \\
\hline Breast texture & & \\
A & 11 & 17 \\
B & 30 & 19 \\
C & 4 & 3 \\
D & 2 & 1 \\
Missing & 0 & 7 \\
\hline Breast sensibility & & \\
A & 3 & 7 \\
B & 18 & 8 \\
C & 20 & 22 \\
D & 3 & 2 \\
Missing & 3 & 8 \\
\hline & &
\end{tabular}

\begin{tabular}{lcc}
\hline & Patient & Surgeon \\
\hline Position of the NAC & 33 & 25 \\
A & 10 & 10 \\
B & 0 & 2 \\
C & 3 & 2 \\
D & 1 & 8 \\
Missing & & \\
Appearance of the NAC & 35 & 23 \\
A & 8 & 12 \\
B & 1 & 4 \\
C & 2 & 1 \\
D & 1 & 7 \\
Missing & & \\
\hline Sensibility of the NAC & 6 & 5 \\
A & 17 & 15 \\
B & 14 & 16 \\
C & 4 & 1 \\
D & 6 & 10 \\
Missing & 6 & \\
Symmetry & & 22 \\
A & 20 & 10 \\
B & 19 & 6 \\
C & 6 & 1 \\
D & 1 & 8 \\
Missing & 1 & 15 \\
\hline Overall impression & & 19 \\
A & 25 & 5 \\
B & 19 & 2 \\
C & 2 & \\
D & 1 & 0 \\
Missing & 0 & \\
\hline & & \\
\hline & & \\
\hline
\end{tabular}

The four independent surgeons' evaluation (for the first sixty patients) showed excellent esthetical outcomes with a mean mark to 16/20.

Quality of life (sexual and physical wellness) evaluated 12 months after surgery was not affected by the mastectomy (Table 4 ).

\section{Discussion}

This is a prospective study of the largest series of robotic nipple sparing mastectomy. In this series, $6.5 \%$ of procedures lead to an implant

Table 4. Breast $Q$ results

\begin{tabular}{lccc}
\hline & $\begin{array}{c}\text { Mean } \\
\text { pre-operative } \\
\text { score }\end{array}$ & $\begin{array}{c}\text { Mean } \\
\text { post-operative } \\
\text { score }\end{array}$ & \\
\hline $\begin{array}{l}\text { Physical wellness } \\
n=40 / 79\end{array}$ & 22 & 25,3 & $p=0,13$ \\
$\begin{array}{l}\text { Quality of life and sexuality } \\
n=38 / 79\end{array}$ & 24 & 24 & $p=0,38$ \\
\hline
\end{tabular}

loss: 5 losses following an infection, 5 losses caused by skin flap or NAC necrosis, and 2 losses due to severe periprosthetic capsula.

We reported here a very low rate of skin flap or NAC necrosis (1.5\%). In our first preliminary series, and in Toesca's series, no case of necrosis occurred (15). The necrosis rate in the literature in open surgery is generally higher. Endara et al. noted a necrosis rate of $4.5 \%$, not significantly different $(p=0.12)(18)$. In their series, Vita et al. reported a rate of $8.2 \%$ of skin flap or NAC necrosis, which is significantly higher than our necrosis rate $(p=0.002)$ (19). Piper et al. published a large meta-analysis including 27 studies, 3331 procedures, with a necrosis rate estimated at $9.5 \% \quad(9.1 \%$ of superficial necrosis and $2 \%$ of major necrosis) (20).

We noted an infection rate of $6.5 \%$, which is comparable to the values reported in the literature. Choi et al observed an infection 
rate of $4.4 \%$ in their series of 160 mastec- $^{-}$ tomies (9).

Lai et al. compared robotic NSM with conventional NSM (respectively 54 and 62 procedures); complication rates were $41 \%$ and $46.8 \%$ respectively, which is not significantly different (21). In a recent study, Houvenaeghel et al. reported 87 procedures of robotic NSM and 142 procedures of conventional NSM (17). Despite several significant higher rates of risks factors for complications in the robotic group, there was no significant difference for breast complications between the two groups, $21.8 \%$ and $27.5 \%$ for robotic NSM and conventional NSM groups, respectively. Lee et al. compared high-grade complication rates between open surgery and robotic surgery for this procedure (16). In their series, RNSM was associated with lower rates of high-grade post-operative complications ( $34.8 \%$ vs. $17.1 \%$, $\mathrm{p}=0.031$.

These first results are very encouraging. Necrosis rate with the robotic procedure does not seem higher than necrosis rate with open surgery, and might even be lower.

The major interest of robotic nipple sparing mastectomy is to enable complete gland resection without using retractors, through an incision leaving a satisfactory scar. Indeed, retractors could aggravate skin flap ischemia. In this procedure, working space is created by continuous carbon dioxide insufflation. Besides, the operator assistant checks that there is no pressure exerted on the skin flap. This could explain the very low necrosis rate with the robotic procedure. Moreover, there is no contact between the prothesis and the scar, since the incision is outside the breast. This may reduce infection risk.

These complication rates will most likely continue to decrease with operators' experience. Houvenaeghel et al. reported a series of 100 robotic nipple sparing mastectomies. It underlines the importance of operator's and assistants' learning curve (14). Operating and docking times have been substantially reduced with the surgical team's experience. Toesca describes a short learning curve with operating times similar to those in open surgery from the third procedure (15).

Esthetical results evaluated by the patient and the surgeon were mostly very satisfying and quality of life was not affected by the mastectomy. Nipple-sparing- mastectomies are generally performed on young and healthy patients, as prophylactic surgeries. The scar on the breast could generate negative feelings. It could even be an obstacle to the acceptance of the surgery, in high-risk patients. This surgical procedure performed without visible scar could improve the experience of the patients.

\section{Conclusion}

Robotic NSM is a safe and reproducible procedure that provides breast reconstruction without scar on the breast. The robotic nipplesparing-mastectomy is at its early stages. These first results are very promising, but the surgical procedure will continue to improve with the experience of the operating team. The operating time and the complication rate will certainly decrease, in accordance with the learning curve. More studies and long-term data are needed to confirm the reduced rate of skin and NAC necrosis compared with the open technique, the oncological safety, and the esthetic stability of the result.

\section{Conflict of Interest}

The authors declare no conflicts of interests.

\section{References}

1. Mota BS, Riera R, Ricci MD, Barrett J, de Castria TB, Atallah ÁN, et al. Nippleand areola-sparing mastectomy for the treatment of breast cancer. Cochrane Database Syst Rev. 2016;11(11):CD008932.

2. Lostumbo L, Carbine NE, Wallace J. Prophylactic mastectomy for the prevention of breast cancer. Cochrane Database Syst Rev. 2010;(11): CD002748.

3. Donovan CA, Harit AP, Chung A, Bao J, Giuliano AE, Amersi F. Oncological and Surgical Outcomes After Nipple-Sparing Mastectomy: Do Incisions Matter? Ann Surg Oncol. 2016;23(10): 3226-31.

4. Wagner JL, Fearmonti R, Hunt KK, Hwang RF, Meric-Bernstam F, Kuerer $\mathrm{HM}$, et al. Prospective evaluation of the nipple-areola complex sparing mastectomy for risk reduction and for early-stage breast cancer. Ann Surg Oncol. 2012;19(4):1137-44

5. Choi M, Frey JD, Salibian AA, Karp NS. Nipple-Areola Complex Malposition in Nipple-Sparing Mastectomy: A Review of Risk Factors and Corrective 
Techniques from Greater than 1000 Reconstructions. Plast Reconstr Surg. 2017;140(2):247e-57e.

6. Lai H-W, Chen S-T, Chen D-R, Chen S-L, Chang T-W, Kuo S-J, et al. Current Trends in and Indications for Endoscopy-Assisted Breast Surgery for Breas Cancer: Results from a Six-Year Study Conducted by the Taiwan Endoscopic Breast Surgery Cooperative Group. PLoS One. 2016;11(3):e0150310.

7. Hung C-S, Chang S-W, Liao L-M, Huang C-C, Tu S-H, Chen S-T, et al. The learning curve of endoscopic total mastectomy in Taiwan: A multi-center study. PLoS One. 2017;12(6):e0178251.

8. Ingram D. Is it time for breast cancer surgeons to embrace endoscopicassisted mastectomy? ANZ J Surg. 2008;78(10):837-8

9. Choi M, Frey JD, Alperovich M, Levine JP, Karp NS. "Breast in a Day": Examining Single-Stage Immediate, Permanent Implant Reconstruction in Nipple-Sparing Mastectomy. Plast Reconstr Surg. 2016;138(2):184e-91e.

10. Sarfati B, Honart JF, Leymarie N, Kolb F, Rimareix F. Robotic-assisted Nipple Sparing Mastectomy: A feasibility study on cadaveric models. J Plast Reconstr Aesthet Surg. 2016:69(11):1571-2.

11. Sarfati B, Struk S, Leymarie N, Honart J-F, Alkhashnam H, Kolb F, et al Robotic Nipple-Sparing Mastectomy with Immediate Prosthetic Breas Reconstruction: Surgical Technique. Plast Reconstr Surg. 2018;142(3): 624-7.

12. Sarfati B, Struk S, Leymarie N, Honart J-F, Alkhashnam H, Tran de Fremicourt K, et al. Robotic Prophylactic Nipple-Sparing Mastectomy with Immediate Prosthetic Breast Reconstruction: A Prospective Study. Ann Surg Oncol. 2018;25(9):2579-86.

13. Sarfati B, Honart J-F, Leymarie N, Rimareix F, Al Khashnam H, Kolb F Robotic da Vinci Xi-assisted nipple-sparing mastectomy: First clinica report. Breast J. 2018;24(3):373-6.
14. Houvenaeghel G, Bannier M, Rua S, Barrou J, Heinemann M, Knight S, et al. Robotic breast and reconstructive surgery: 100 procedures in 2-years for 80 patients. Surg Oncol. 2019;31:38-45.

15. Toesca A, Peradze N, Manconi A, Galimberti V, Intra M, Colleoni M, et al. Robotic nipple-sparing mastectomy for the treatment of breast cancer: Feasibility and safety study. Breast. 2017;31:51-56. Epub 2016 Nov 2.

16. Lee J, Park HS, Lee H, Lee DW, Song SY, Lew DH, et al. Post-Operative Complications and Nipple Necrosis Rates Between Conventional and Robotic Nipple-Sparing Mastectomy. Front Oncol. 2021;10:594388. eCollection 2020.

17. Houvenaeghel G, Barrou J, Jauffret C, Rua S, Sabiani L, Van Troy A, et al. Robotic Versus Conventional Nipple-Sparing Mastectomy With Immediate Breast Reconstruction. Front Oncol. 2021 Mar 4; 11:637049.

18. Endara M, Chen D, Verma K, Nahabedian MY, Spear SL. Breast reconstruction following nipple-sparing mastectomy: a systematic review of the literature with pooled analysis. Plast Reconstr Surg. 2013;132(5):1043-54.

19. De Vita R, Zoccali G, Buccheri EM, Costantini M, Botti C, Pozzi M. Outcome Evaluation after 2023 Nipple-Sparing Mastectomies: Our Experience. Plast Reconstr Surg. 2017;139(2):335e-47e.

20. Piper M, Peled AW, Foster RD, Moore DH, Esserman LJ. Total skin-sparing mastectomy: a systematic review of oncologic outcomes and postoperative complications. Ann Plast Surg. 2013; 70(4):435-7.

21. Lai H-W, Chen S-T, Mok CW, Lin Y-J, Wu H-K, Lin S-L, et al. Robotic versus conventional nipple sparing mastectomy and immediate gel implant breast reconstruction in the management of breast cancer- A case control comparison study with analysis of clinical outcome, medical cost, and patient-reported cosmetic results. J Plast Reconstr Aesthet Surg. 2020; 73(8):1514-25 